\title{
Culverts in paved roads as suitable passages for Neotropical fish species
}

\author{
Sergio Makrakis ${ }^{1,3}$, Theodore Castro-Santos ${ }^{2}$, Maristela Cavicchioli Makrakis ${ }^{1,3}$, \\ Ricardo Luiz Wagner ${ }^{3}$ and Maurício Spagnolo Adames ${ }^{3}$
}

Improperly installed or poorly maintained culverts can pose a serious threat to fish by disrupting their habitat and endangering spawning success. Road culverts that are not designed for fish passage frequently can become obstacles. This can be especially problematic for migratory species, but can lead to fragmentation of resident populations as well. This study evaluated 40 culverts of 29 sites within a $25-\mathrm{km}$ radius from Toledo city, Paraná State, southern Brazil, with respect to their likely effects on movement of the local ichthyofauna. We collected data on the shape and length of culverts, culvert material, waterfall height, water column depth, slope, and estimated flow velocity. Culverts were categorized by level of barrier risk for upstream migration: high, medium, low, and impassable, as well as the type of barrier posed (fall height, depth, length and velocity). Most of culverts analyzed were considered potential barriers to fish movement, with $45 \%$ classified as impassible, $45 \%$ as high risk, $10 \%$ as medium risk, and no culverts as low risk. Brazilian culverts as fishways will require additional monitoring and studies to corroborate the premises proposed in the present study. Road culvert projects that are properly built and maintained will be able to simultaneously improve function of roadways and protect fish populations.

Bueiros incorretamente instalados ou mal conservados podem representar uma séria ameaça para os peixes por fragmentar o seu habitat e comprometer o sucesso da desova. Bueiros em estradas que não são projetados para passagem de peixes freqüentemente tornam-se obstáculos. Isso pode ser especialmente problemático para as espécies migratórias, mas também pode levar à fragmentação das populações de peixes residentes. Este estudo avaliou 29 locais com 40 bueiros dentro de um raio de $25 \mathrm{~km}$ de Toledo, Estado do Paraná, sul do Brasil, com relação aos seus prováveis efeitos sobre a movimentação da ictiofauna local. Dados foram coletados sobre a forma e o comprimento dos bueiros, material utilizado, altura da queda de água, profundidade, declividade e velocidade estimada do fluxo. Os bueiros foram categorizados pelo nível de risco como barreira a migração ascendente: alto, médio, baixo e impassável, bem como o tipo de barreira imposta (altura da queda, profundidade, comprimento e velocidade). A maioria dos bueiros analisados foi considerada barreira para o movimento dos peixes, com $45 \%$ classificados como intransitáveis, $45 \%$ como alto risco, $10 \%$ como médio risco, não havendo bueiros com baixo risco. Bueiros brasileiros como passagens para peixes necessitarão de monitoramento e estudos adicionais para corroborar as premissas propostas no presente estudo. Projetos de bueiros em estradas que estão devidamente construídos e mantidos serão capazes de simultaneamente melhorar a função das rodovias e proteger as populações de peixes.

Key words: Barriers, Criteria for culverts, Road crossing, Stream.

\section{Introduction}

Fish populations depend strongly on characteristics of the habitat where they live and perform biological functions (reproduction, feeding, locomotion, etc.). Barriers to fish movement restrict the ability of them to access habitats, and can reduce their quality both upstream and downstream of the barrier (Morita \& Yamamoto, 2002). Anthropogenic barriers are a primary factor affecting movements of fishes (Fullerton et al., 2010). While the effects of dams are well-known, road crossings can be far more ubiquitous and so should be a major concern for managers. Most road culverts are designed solely for the purpose of moving water beneath a roadway, with no consideration of effects on animal movement.

${ }^{1}$ Universidade Estadual do Oeste do Paraná. Grupo de Pesquisa em Tecnologia de Produção e Conservação de Recursos Pesqueiros e Hídricos (GETECH). Rua da Faculdade, 645, Jardim Santa Maria. 85903-000. Toledo, PR, Brazil. makrakis@terra.com.br (SM); mmakrakis@terra.com.br (MCM)

${ }^{2}$ Silvio O. Conte Anadromous Fish Research Center, U. S. Geological Survey, Leetown Science Center, One Migratory Way, P.O. Box 796, Turners Falls, MA 01376, U.S.A. TCastro_Santos@usgs.gov

${ }^{3}$ Universidade Estadual do Oeste do Paraná. Programa de Pós-Graduação em Recursos Pesqueiros e Engenharia de Pesca. Rua da Faculdade, 645. Jardim Santa Maria, 85903-000 Toledo, PR, Brazil.ricabatata@hotmail.com (RLW), mauricio_adames@hotmail.com (MAS) 
Culverts are defined as a hydraulic structure to convey surface water runoff under highway, road, railroad, or other embankment (Clay, 1995). Culverts vary in sizes, shapes, and materials, and these factors, along with several others, affect their capacity and overall performance. Sizes and shapes may vary from small circular pipes to extremely large arch sections that are sometimes used in place of bridges (Ead et al., 2002). The most commonly used culvert shape is circular, but arches, boxes, rectangular and elliptical shapes are used, as well they may be simple, with only one or multiple culvert, over a culvert.

A culvert with a rigid construction placed in a water flow always changes the environment. Changes in soil use due to urbanization, agriculture, and other land-use practices can affect flows and bed load transport. One consequence of this is that culverts are frequently unable to adapt to channel degradation, becoming 'perched', or elevated above the streambed. When this occurs, culverts can become impassable barriers to fish movement. They can act as barriers in other ways as well, including insufficient depth or quantity of flow and excessive flow velocity or turbulence. Sediment and debris accumulation can also inhibit passage (Bates et al., 2003).

Precautions are recommended by engineers when installing culverts to minimize the impacts on fish and their habitats (Chilibeck, 1992). There is a general trend to associate the concept of obstruction for fish migration with the height of a waterfall or cascade, but obstruction is more complex than that. Whether the culvert can be passed or not will depend on the hydrodynamic conditions of the obstacle downstream (velocity, water depth, fall configuration, aeration, turbulence), and on the swimming and leaping ability of the fish species considered (Larinier, 2002). However, even culverts that are correctly designed and installed do not assure fish passage because its main purpose is to drain river flow under a road. Therefore, it is fundamental to consider the type of material [i.e., $\mathrm{n}$ (roughness) in Manning's formula], the slope (S) and the wetted perimeter (R). These factors must be adjusted to meet the swimming capacity to allow free movement of fish by the culvert (Clay, 1995).

Studies in other countries show that the lack of resting pools for fish, in both culvert extremities, hinders the recuperation needed to transpose the rest of the obstacle (Bates et al., 2003). Some culverts are only seasonal obstacles, acting as barriers when the water level is low. All situations previously mentioned as barriers to adult fish movement are also frequently prejudicial to the juveniles of the species (Toepfer et al., 1999). Although standards for stream cross sections are well known, negligence and priority of costs have led to unsatisfying projects and installations in most cases. Negative effects of culverts and deficient building practices have been reported many times (Mcclellan, 1970; Jones et al., 1974; Larson, 1976).

Culverts create more barriers to fish passage than other structures, but due to cost limitations, corrugated metal culverts are frequently installed, instead of building environmentally correct bridges (Warren \& Pardew, 1998; Harper \& Quigley, 2000). Problems associated with culvert passage are well- documented in the Northern Hemisphere (Bates et al., 2003; Nislow et al., 2011). In Brazil, however, there are no studies on this subject, and this study represents the first effort to document this issue in Neotropical streams. Physical dimensions of culverts can be precisely measured, and these measurements may indicate the degree to which a structure is a barrier. Thus, the aim of the study was to evaluate the potential of culverts to be passable or impassable to fish movement.

\section{Material and Methods}

An inventory of the culverts in southern Brazil was carried out from November 2008 to October 2009. The study area comprised a region within a $25-\mathrm{km}$ radius of the Toledo city, Paraná State, Brazil. In this area were found 40 culverts in 29 sites due to most of the sites exhibited more than one culvert (Fig. 1) covering 20 streams and 3 rivers. Culverts were mapped and described for all paved roads that cross rivers and streams in the study area.

As part of the description and mapping of the culverts were estimated water velocity using Manning's formula: $V=$ $(1 / n) R^{2 / 3} S^{1 / 2}$, where, $V$ : average discharge velocity $(\mathrm{m} / \mathrm{s}) ; n$ : roughness coefficient of the culvert material; $R$ : average of the hydraulic radius - cross sectional area of flow divided by wetted perimeter $(\mathrm{m})$; $S$ : channel bed slope $(\mathrm{m} / \mathrm{m})$; outlet perch was the elevation of the culvert outlet minus the elevation of the downstream water. Measurements of water depth, fall height downstream, length, width of box culverts, and diameter of circular culverts also were made using a tape. Roughness evaluation was realized following Kenney et al. (1992). Culvert slope was calculated as gain in elevation of the culvert divided by the length of the culvert expressed as percentage. Slope was measured using a precision level (Leica, model Basic Level) express by level difference between P1 P2 (Fig. 2). Culvert slope $x$ length was the slope (\%) of the culvert times the length of the culvert.

After the inventory, data were tabulated, analyzed and ranked according to characteristics of the culverts, such as: outlet drop and outlet perch (jump barrier), water depth (depth barrier), velocity (velocity barrier) and length $\mathrm{x}$ slope (exhaustion barrier) (modified from Coffman, 2005).

For scoring the potential of the impassable risk of culverts (blocking the fish passage) scores were defined as: 1 (Lowcompletely passable), 0.75 (Medium), 0.25 (High) and 0 (Impassable). The intervals proposed for the characteristics were considered according to Table 1. After scoring, the culverts were classified according to the index of connectivity proposed $\left(I_{C}\right)$, which is equal to the product of each component affecting the ability of fish to pass:

$$
I_{C}=H_{P} \times D_{f} \times Q \times(L \times S)
$$

Where the Index of connectivity $\left(I_{c}\right)$ is the product of the passability indices for height of perch $\left(H_{P}\right)$, depth of flow 
$\left(D_{f}\right)$, discharge $(Q)$, length $(L)$ and slope $(S)$. We scaled each component from 0 (impassable) to 1 (completely passable). Intervals were adopted for scores ranging from low to potential impassable for ascending fish movement. Thus, we created the criteria that ranged from 0 to 1 , in four intervals (impassable, high, medium, and low) associated with the physical and hydraulic characteristics that may affect fish performance in achieving transposed upward culvert.

Culverts with values over $0.40 \mathrm{~m}$ for fall height downstream were considered as culverts that completely block the fish passage (jump barrier), and attributed score zero. Where slope $(\%)$ x length $(m)>200$, flow velocities

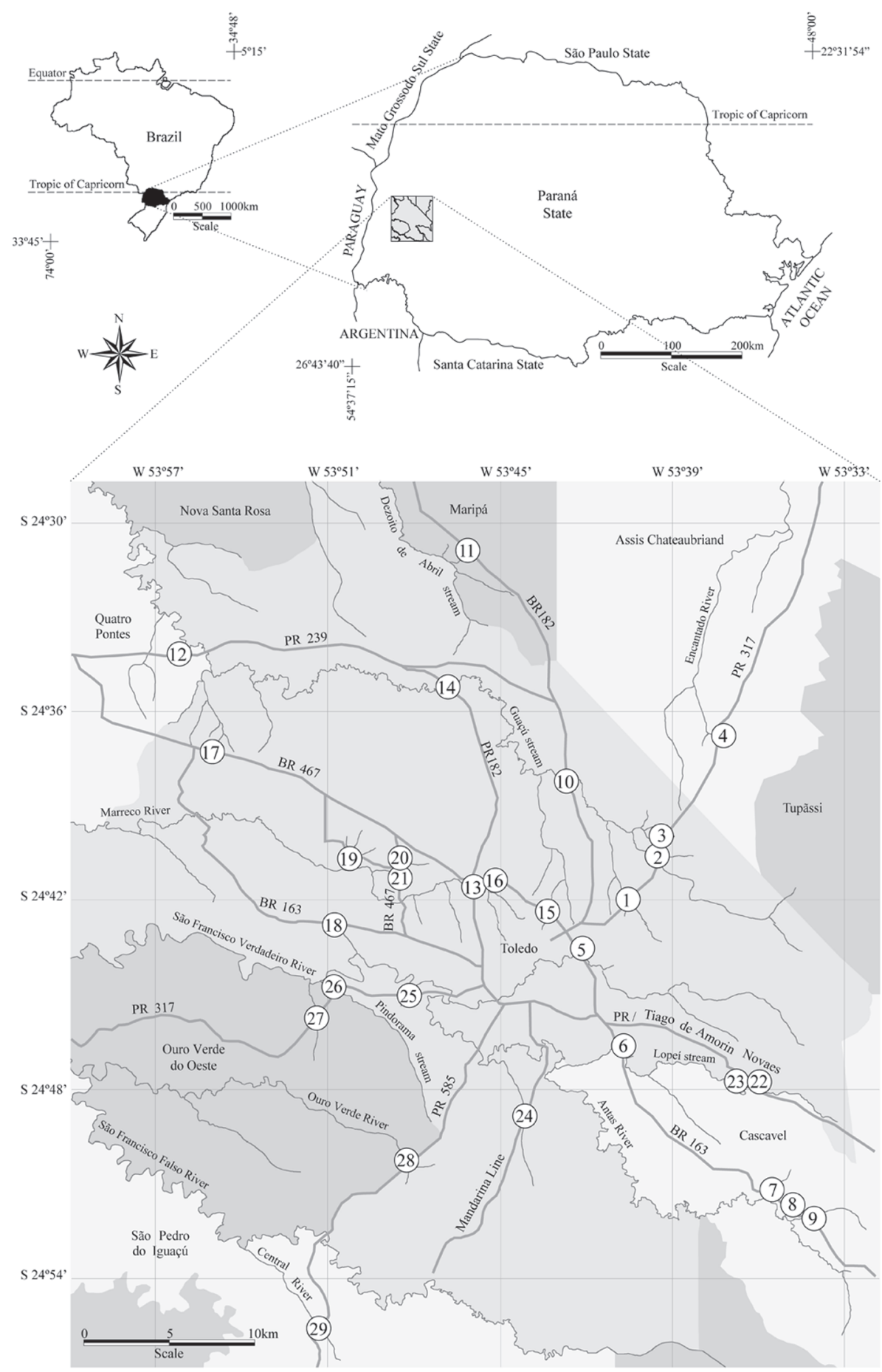

Fig. 1. Study area: location of culverts within a radius of $25 \mathrm{~km}$ from the Toledo City, Paraná, Brazil. 


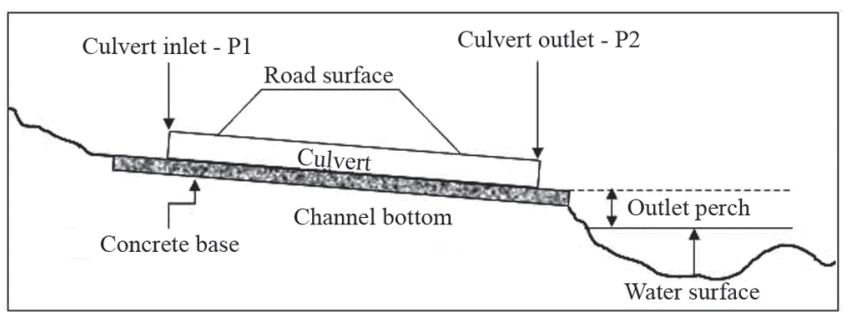

Fig. 2. Selected measurements used to classify culverts. Outlet perch $=$ elevation of culvert outlet (P2) - water surface (modified from Nislow et al., 2011).

were considered too high to allow for passage of all fish species, and so was considered an impassable barrier to upstream movement (Table 1).

In order to define categories of culvert characteristics, we considered the high diversity of the fish species in Neotropical rivers and streams, mostly of small-sized species, and especially the high abundance of Siluriformes (catfishes and armored catfishes locally known as 'mandis', 'bagres', and 'cascudos'), which exhibit bottom swimming behavior and do not jump. Such premises resulted in categories, for instance the fall height, with relatively restrictive values to fish passage. This statement based on results of the study conducted to assess fish species composition and abundance between upstream and downstream stretches of two culverts (Mariano, 2011). This assessment was realized after the inventory of the culverts in sites 23 and 26, circular and box culverts, respectively (Table 1). The sampling occurred monthly from November 2009 to October 2010 using different fishing gears (for more detail see Celestino et al., 2012) suited to several stream environments. The fish species abundance, richness, and diversity showed different patterns in particular between the upstream and downstream stretches of the circular culvert (site 23), especially for Siluriformes (mainly Loricariidae), with higher values found in downstream stretch (Mariano, 2011). According to Nislow et al. (2011), differences in local abundance and species richness may serve as indicators of the extent to which road crossings are barriers to fish movement and help determine whether road-crossing improvements have restored connectivity to stream fish populations and communities.

Table 1. Classification and scores for the proposed ranges to culvert characteristics.

\begin{tabular}{lccccc}
\hline Classification & Scores & $\begin{array}{c}\text { Outlet drop } \\
(\mathrm{cm})\end{array}$ & $\begin{array}{c}\text { Depth } \\
(\mathrm{cm})\end{array}$ & $\begin{array}{c}\text { Water flow } \\
(\mathrm{m} / \mathrm{s})\end{array}$ & $\begin{array}{c}\text { Slope } \mathrm{x} \\
\text { Length }\end{array}$ \\
\hline Impassible & 0 & $>40$ & - & - & $>200$ \\
High & 0.25 & $>20 \leq 40$ & $<10$ & $>1.5$ & $>100 \leq 200$ \\
Medium & 0.75 & $>10 \leq 20$ & $10.0-15.0$ & $0.5-1.5$ & $>25 \leq 100$ \\
Low & 1 & $\leq 10$ & $>15$ & $<0.5$ & $\leq 25$ \\
\hline
\end{tabular}

\section{Results}

The evaluation of the 40 culverts in 29 sites studied indicated that fish find potentially impassable barriers in 45 $\%(\mathrm{~N}=18)$ of the culverts: the index of connectivity was equal to zero (Table 2), $45 \%(\mathrm{~N}=18)$ showed high risk, $10 \%(\mathrm{~N}$ $=4)$ medium risk, and none with low risk.

Culvert length varied from 7.0 to $81.4 \mathrm{~m}$, with an average length of $31.0 \mathrm{~m}$. Slopes varied from 0 to $3.0 \%$, with an average of $1.2 \%$. Outlet drop ranged from 0.0 to $116.0 \mathrm{~cm}$, with an average of $36.0 \mathrm{~cm}$ (Table 2).

The velocities calculated by the Manning's formula ranged from 0.0 to $4.25 \mathrm{~m} / \mathrm{s}$, with an average of $0.83 \mathrm{~m} / \mathrm{s}$. Two forms of perch in the culverts were observed, and the consequent formation of a barrier, depending on their heights, may be impassable for some Siluriformes, due to the concrete base that holds the culvert (Fig. 3a-c), and the other due to the circular culvert perch (Fig. 3b). Multiple culverts (Fig. 3d-e) were also found, i.e., more than one culvert at the same place, 9 sites $(31 \%)$ have more than one.

The results presented in Table 2, with their respective physical and hydraulic data, were compared with recommendations for building new culverts. Out of the studied culverts, $55 \%$ were box and the $45 \%$ were circular (Fig. 3d-e; Table 2). The observed materials used for construction of the culverts were smooth concrete, corrugated metal and stony soil, resulting in $87.5,10.0$, and $2.50 \%$, respectively.

\section{Discussion}

Serious concerns proceed from the scenario envisioned in this study where the majority of culverts were considered barriers to fish movement; $45 \%$ are impassable, and another $45 \%$ also have potentially high risk according to the criteria and approach used. In a study that selected 50 culverts at random in Nova Scotia, Langill \& Zamora (2002) found a value very similar to the present study, where $58 \%$ of the culverts were barriers to fish migration. However, current survey methodologies are biased towards specific structures, primarily culverts and economically significant fish (Kemp \& O'Hanley, 2010), and assessment criteria are often based on swimming capabilities of upstream migrating adult salmonids, while ignoring other life-stages, non-salmonid species, downstream migration and behavior. The development of comprehensive and centrally managed geospatial inventories of barriers would greatly aid efforts like this one (Kemp O'Hanley, 2010).

The major factor possibly blocking the passage of fish to the upward movement in this study was the perch of the culverts, where it was observed values above $100 \mathrm{~cm}$ of height, with an average of $36 \mathrm{~cm}$ in the 40 culverts studied. Outlet drop was the most important factor affecting passage success: low probability of passage for small trout $(<100$ $\mathrm{mm}$ fork length) at outlet drops greater than $15 \mathrm{~cm}$ and for large trout $(>100 \mathrm{~mm})$ at outlet drops greater than $21 \mathrm{~cm}$ (Burford et al., 2009). 
Table 2. Results from culverts analyzed. The data refer to rivers, names of paved roads that intersect the culvert. Box (B). Circular (C). Type of material (M). Smooth concrete (sc). Corrugated metal (com); Stony soil (ss). Outlet drop (OD). Length (L). Depth of the water column (D). Slope (S). Flow velocity (V). Percent (\%). Not available (?). Multiple culverts followed by the letters $\mathrm{a}, \mathrm{b}$, and $\mathrm{c}$.

\begin{tabular}{|c|c|c|c|c|c|c|c|c|c|c|c|c|}
\hline Sites & River/stream & Road & Shape & M & $\begin{array}{l}\text { OD } \\
(\mathrm{cm})\end{array}$ & $\begin{array}{l}\mathrm{L} \\
(\mathrm{m})\end{array}$ & $\begin{array}{l}\mathrm{D} \\
(\mathrm{cm})\end{array}$ & $\begin{array}{c}\mathrm{S} \\
(\%)\end{array}$ & $\begin{array}{c}\mathrm{V} \\
(\mathrm{m} / \mathrm{s})\end{array}$ & S X L & $\begin{array}{c}\text { Index of } \\
\text { connectivity }\end{array}$ & $\begin{array}{c}\text { Risk of } \\
\text { fragmentation }\end{array}$ \\
\hline 1 & Branca Stream & BR-317 & B & $\mathrm{sc}$ & 0.00 & 36.30 & 10.67 & 0.44 & 0.60 & 16 & 0.56 & Medium \\
\hline 2 & Guaçú Stream & BR-317 & B & $\mathrm{sc}$ & 0.00 & 61.80 & 42.07 & 0.21 & 0.93 & 13 & 0.75 & Medium \\
\hline 3 & Barreiro River & BR-317 & B & $\mathrm{sc}$ & 70.00 & 35.90 & 4.87 & 1.09 & 0.57 & 39 & 0.00 & Impassible \\
\hline 4 & Timbó Stream & BR-317 & B & $\mathrm{sc}$ & 45.00 & 22.30 & 2.03 & 1.17 & 0.57 & 26 & 0.00 & Impassible \\
\hline 5 & São Pedro Stream & BR-467 & $\mathrm{C}$ & com & 116.00 & 32.60 & 10.03 & $?$ & ? & 0 & 0.00 & Impassible \\
\hline 6 & Pernilongo Stream & BR-163 & $\mathrm{C}$ & com & 0.00 & 81.40 & 17.53 & 0.33 & 0.11 & 27 & 0.75 & Medium \\
\hline 7 & - & BR-163 & $\mathrm{C}$ & com & 0.00 & 62.40 & 14.03 & 2.95 & 0.23 & 184 & 0.19 & High \\
\hline 8 & Guaramirin Stream & BR-163 & $\mathrm{C}$ & com & 0.00 & 62.40 & 9.47 & 0.95 & 0.10 & 59 & 0.19 & High \\
\hline $9 \mathrm{a}$ & \multirow{2}{*}{ Ita Stream } & \multirow{2}{*}{ BR-163 } & B & $\mathrm{sc}$ & 0.00 & 74.60 & 19.13 & 0.78 & 1.80 & 58 & 0.19 & High \\
\hline $9 \mathrm{~b}$ & & & B & $\mathrm{sc}$ & 0.00 & 74.60 & 11.50 & 0.78 & 1.36 & 58 & 0.42 & Medium \\
\hline $10 \mathrm{a}$ & \multirow{2}{*}{ Guaçú Stream } & \multirow{2}{*}{ PR-182 } & B & $\mathrm{sc}$ & 0.00 & 54.00 & 0.60 & 0.22 & 0.11 & 12 & 0.25 & High \\
\hline $10 \mathrm{~b}$ & & & B & $\mathrm{sc}$ & 0.00 & 54.00 & 0.73 & 0.22 & 0.13 & 12 & 0.25 & High \\
\hline 11 & Alecrin Stream & PR-182 & $\mathrm{C}$ & $\mathrm{sc}$ & 33.00 & 23.50 & 3.17 & 1.87 & 0.07 & 44 & 0.05 & Impassible \\
\hline $12 \mathrm{a}$ & \multirow{2}{*}{ Perickmayer Stream } & \multirow{2}{*}{ PR-239 } & $\mathrm{C}$ & $\mathrm{sc}$ & 85.00 & 32.80 & 5.50 & 1.95 & 0.14 & 64 & 0.00 & Impassible \\
\hline $12 \mathrm{~b}$ & & & $\mathrm{C}$ & $\mathrm{sc}$ & 85.00 & 32.80 & 8.25 & 1.95 & 0.31 & 64 & 0.00 & Impassible \\
\hline $13 \mathrm{a}$ & \multirow{2}{*}{ Marreco Stream } & \multirow{2}{*}{ Av. Min. Cirne Lima } & B & $\mathrm{sc}$ & 37.00 & 46.25 & 9.83 & 1.06 & 1.49 & 49 & 0.11 & High \\
\hline $13 \mathrm{~b}$ & & & B & $\mathrm{sc}$ & 37.00 & 46.25 & 7.97 & 1.06 & 1.31 & 49 & 0.04 & High \\
\hline 14 & Guaçú Stream & PR-182 & B & ss & 0.00 & 13.70 & 131.33 & 1.90 & 4.25 & 26 & 0.00 & Impassible \\
\hline 15 & Pitanga Stream & BR-467 & B & $\mathrm{sc}$ & 0.00 & 19.52 & 9.10 & 0.41 & 0.89 & 8 & 0.19 & High \\
\hline 16 & Campina Grande Stream & BR-467 & B & $\mathrm{sc}$ & 70.00 & 18.95 & 7.82 & 1.32 & 1.43 & 25 & 0.00 & Impassible \\
\hline 17 & Tigre Stream & BR-467 & $\mathrm{C}$ & $\mathrm{sc}$ & 51.00 & 40.08 & 5.90 & 2.00 & 0.15 & 80 & 0.00 & Impassible \\
\hline 18 & Guaçú Stream & BR-163 & B & $\mathrm{sc}$ & 90.00 & 12.50 & 3.60 & 3.00 & 1.32 & 38 & 0.00 & Impassible \\
\hline 19 a & \multirow{2}{*}{ Tarumã Stream } & \multirow{2}{*}{ Rod. Ernesto Dall'Oglio } & $\mathrm{C}$ & $\mathrm{sc}$ & 23.00 & 7.08 & 15.67 & 0.42 & 0.29 & 3 & 0.25 & High \\
\hline $19 b$ & & & $\mathrm{C}$ & $\mathrm{sc}$ & 42.00 & 7.08 & 22.67 & 0.42 & 0.46 & 3 & 0.00 & Impassible \\
\hline 20 & Água Silvino Stream & OT 105 & $\mathrm{C}$ & $\mathrm{sc}$ & 85.00 & 11.00 & 14.75 & 1.73 & 0.62 & 19 & 0.00 & Impassible \\
\hline 21 & Água Silvino Stream & OT 105 & $\mathrm{C}$ & $\mathrm{sc}$ & 33.00 & 12.00 & 11.70 & 0.46 & 0.24 & 6 & 0.19 & High \\
\hline 22 & \multirow[t]{2}{*}{ Lopeí Stream } & \multirow{2}{*}{ PR/Tiago A. Novaes } & $\mathrm{C}$ & $\mathrm{sc}$ & 20.00 & 12.50 & 7.75 & 0.56 & 0.15 & 7 & 0.19 & High \\
\hline $23 \mathrm{a}$ & & & $\mathrm{C}$ & $\mathrm{sc}$ & 40.00 & 7.00 & 6.77 & 1.86 & 0.18 & 13 & 0.06 & High \\
\hline $23 \mathrm{~b}$ & \multirow[t]{2}{*}{ Lopeí Stream } & \multirow[t]{2}{*}{ PR/Tiago A. Novaes } & $\mathrm{C}$ & $\mathrm{sc}$ & 40.00 & 7.00 & 15.90 & 1.86 & 0.54 & 13 & 0.19 & High \\
\hline $23 \mathrm{c}$ & & & $\mathrm{C}$ & $\mathrm{sc}$ & 40.00 & 7.00 & 25.17 & 1.86 & 0.97 & 13 & 0.19 & High \\
\hline $24 \mathrm{a}$ & \multirow{2}{*}{ Mandarina Stream } & \multirow{2}{*}{ Linha Mandarina } & $\mathrm{C}$ & $\mathrm{sc}$ & 42.00 & 11.00 & 15.90 & 0.09 & 0.14 & 1 & 0.00 & Impassible \\
\hline $24 \mathrm{~b}$ & & & $\mathrm{C}$ & $\mathrm{sc}$ & 42.00 & 11.00 & 9.70 & 0.09 & 0.07 & 1 & 0.00 & Impassible \\
\hline 25 & \multirow[t]{2}{*}{ Cedro Stream } & \multirow[t]{2}{*}{ PR-317 } & B & $\mathrm{sc}$ & 74.00 & 20.90 & 3.17 & 2.30 & 1.07 & 48 & 0.00 & Impassible \\
\hline $26 \mathrm{a}$ & & & B & $\mathrm{sc}$ & 15.00 & 26.60 & 10.20 & 1.09 & 1.56 & 29 & 0.11 & High \\
\hline $26 \mathrm{~b}$ & \multirow[t]{2}{*}{ Pindorama Stream } & \multirow[t]{2}{*}{ PR-317 } & $\mathrm{B}$ & $\mathrm{sc}$ & 15.00 & 26.60 & 7.67 & 1.09 & 1.31 & 29 & 0.11 & High \\
\hline $26 \mathrm{c}$ & & & $\mathrm{B}$ & $\mathrm{sc}$ & 15.00 & 26.60 & 8.33 & 1.09 & 1.38 & 29 & 0.11 & High \\
\hline 27 & Lageado Stream & PR-317 & B & $\mathrm{sc}$ & 110.00 & 15.85 & 36.00 & 1.14 & 3.22 & 18 & 0.00 & Impassible \\
\hline $28 \mathrm{a}$ & \multirow{2}{*}{ Ouro Verde River } & \multirow{2}{*}{ PR-585 } & B & $\mathrm{sc}$ & 58.00 & 28.40 & 3.57 & 1.94 & 1.06 & 55 & 0.00 & Impassible \\
\hline $28 \mathrm{~b}$ & & & B & $\mathrm{sc}$ & 58.00 & 28.40 & 6.97 & 1.94 & 1.61 & 55 & 0.00 & Impassible \\
\hline 29 & Central River & PR-585 & $\mathrm{B}$ & $\mathrm{sc}$ & 30.00 & 32.15 & 7.27 & 1.12 & 1.25 & 36 & 0.04 & High \\
\hline
\end{tabular}

Whereas $36 \%$ of the species composition of the streams studied (Lopeí and Pindorama) are Siluriformes (especially Loricariidae) according to Mariano (2011), and they do not show the ability to jump, the occurrence of most of the culverts with high height may potentiate the blocking of fish in their upstream movements. When overcoming the $0-\mathrm{cm}$ (streaming flow) and 12-cm drops, fish predominantly used swimming behavior, and for the outfall drops of 20 and $26 \mathrm{~cm}$, jumping behavior predominated (Mueller et al., 2008). According to the authors, juveniles of coho salmon are capable of overcoming some degree of culvert perch to move upstream if tailwater pool, water depth, and pool size are sufficient and hydraulic passage conditions inside the culvert are favorable.

The slopes observed in this study were not high, not exceeding 3\%, and therefore not limiting the movement of a fish. However, Poplar-Jeffers et al. (2009) found in Appalachian
Watershed, USA, that most of culverts are obstacles or complete barriers to trout dispersal, and culvert impassability was higher in small streams with slopes exceeding 3-5\%, suggesting a direct relationship between slope and impassability. Moreover, Price et al. (2010) in the Puget Sound Region of Washington State verified culverts permitted for fish passage under the Washington Department of Fish and Wildlife's (WDFW) hydraulic project approval (HPA) as noslope (one of the most common design types) or as an unknown design type were barriers in $45 \%$ of cases.

Most of the culverts evaluated in this study were made of smoothed concrete. However, the preferred shape for fish passage is the bottomless culvert, i.e., the one that follows the natural flow of the river. The next choice would be the corrugated metal culvert that enables a maximum value of Manning's $n$. During low-flow conditions, depth of flow in 


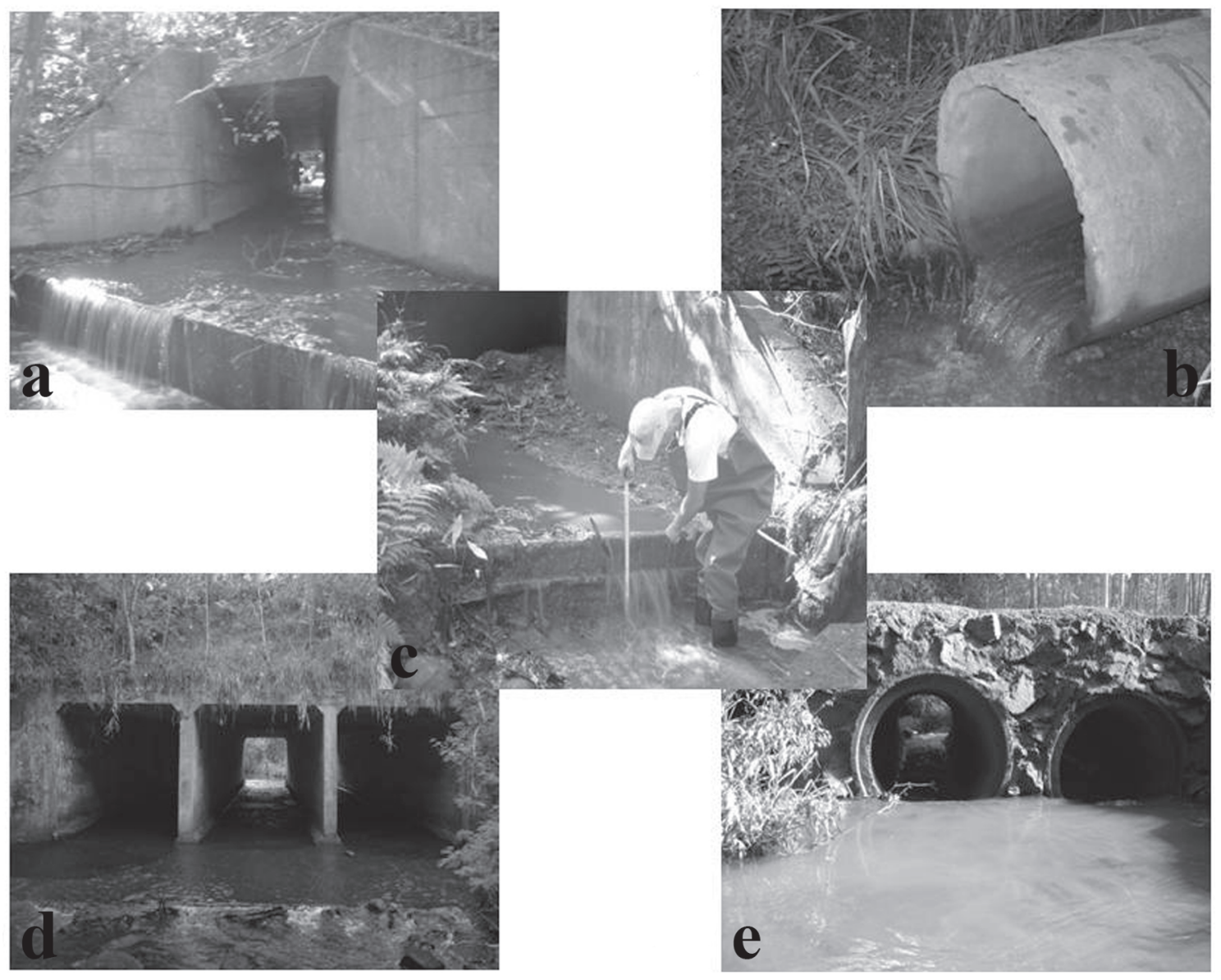

Fig. 3. Some culverts in the study area: a) box shape, with an exposing the concrete base; b) circular shape of concrete and perched; c) measurement of the height of fall; d) multiple culverts in Pindorama Stream, and e) multiple culverts in Lopeí Stream.

large culverts can be very shallow, to the extent that fish are unable to swim (Clay, 1995). This can also occur when multiple culverts are built, as well as for box culverts, which are flat and have a shallow bottom surface (Clay, 1995). Nevertheless, the increased roughness of corrugations adds to turbulence (Liao, 2007), and we do not understand well how turbulence affects swimming ability.

Few data are available on swimming abilities of neotropical fishes. The available data, however, suggest that these species (Leporinus reinhardt and Pimelodus maculatus) have greater swimming abilities than their northern counterparts (Santos et al., 2007, 2008). Fish can reach remarkable burst swimming speed, but they might not be able to sustain this speed in high velocity waters, along the whole length of a culvert. Swimming speeds vary according to species, size (Webb, 1975), body shape (Webb, 1978; Taylor \& Mcphail, 1985), and life cycle stage (Beamish, 1978). Although velocity barriers are known to exist, it is also true that many species of fish are less likely to enter a culvert or open channel without adequate flow. Several studies have shown that entry rates increase at higher velocity, meaning that simply reducing flow velocities is not sufficient to optimize passage (Weaver, 1963; Monk et al., 1989; Castro-Santos, 2004).

The wide range for water column depths found in the culverts $(2.0$ to $130.0 \mathrm{~cm}$ ) is worrying especially during drought periods that exhibit lower values. A minimal water depth of 15.0 $\mathrm{cm}$ is recommended (British Columbia Ministry of Forests, 2002). British Columbia Ministry of Transportation and Highways (2000) recommends that the water depth inside the culvert should follow the natural level of the stream, or be at least 23.0 $\mathrm{cm}$, to allow passage of adult fish. Water depth must be enough to allow fish to remain completely immerse and not to scrape the culvert bottom. Depending on the flow, fish can migrate during the hot summer, searching for colder waters, with higher oxygen levels. Low water level can create a bottleneck, which affects the whole section of the culvert flow.

When culverts have lower roughness and greater slope than the adjacent stream, flow accelerates resulting in a greater velocity at the downstream end. This accelerated erosion to lead to perched culverts observed in this study in circular culvert, and it also can expose the concrete base verified in box culvert (see Fig. 3a-b). Many fish species are 
not able to leap and cannot ascend falls that are even a few centimeters high such as 'cascudos' (Hypostomus spp.). Therefore, culverts need to be filled with foundation rocks and concrete bafflers that hinder erosive processes and, consequently, perching (British Columbia Ministry of Forests, 2002).

In Brazil, the National Department of Transportation Infrastructure (Departamento Nacional de Infraestrutura de Transportes - DNIT) has technical standards for the execution of culverts (NORMA DNIT 023/2006 - ES, NORMA DNIT 024/2004 - ES, NORMA DNIT 025/2004 - ES) (DNIT, 2004ac). These technical standards concern environmental management only during culvert construction, factors that affect the road and engineering prerequisites; there is no reference on providing conditions for fish passage. Meanwhile, in the United States, Canada and some European countries, technical standards and bulletins emphasize that the implementation and suitability of road culverts must be fish-friendly (British Columbia Ministry of Forests, 2002), i.e. they must enable fish passage. Proposed designs for fish friendly culverts, which are designed for fish passage, were drawn up by government institutions in many countries (Bates, 1999; British Columbia Ministry of Forests, 2002; WDFW, 2003).

Our study was able to inventory many culverts with high potential to be impassable to fish movement. Studies that assess and monitoring the fish passages at Brazilian culverts, i.e. based on fish telemetry (Castro-Santos et al., 1996) are needed to corroborate the premises proposed in the present study. Physical, biological and ecological assessment of culverts at streams can powerfully demonstrate the level of habitat fragmentation, and proper culvert design and installation on roads, as well as their maintenance, will be able to prevent roadways from drainage problems and to protect fish populations.

\section{Acknowledgments}

Project supported by CNPq - Edital MCT/CNPq No $14 /$ 2008 - Process number: 476060/2008-7.

\section{Literature Cited}

Bates, K. 1999. Fish passage design at road culverts: A design manual for fish passage at road crossings. Washington Department of Fish and Wildlife. Olympia, WA.

Bates, K. K., B. Barnard, B. Heiner, P. Klavas \& P. D. Powers. 2003. Design of Road Culverts for Fish Passage. Washington Department of Fish and Wildlife, 110p.

Beamish, F. W. H. 1978. Swimming capacity. Pp. 101-187. In: Hoar, W. S., D. J. Randall \& J. R. Brett. (Eds.). Fish Physiology, New York, Academic Press, New York, USA, 576p.

British Columbia Ministry of Forests. 2002. Fish-stream crossing guidebook. Forestry Practices Branch, Ministry of Forestry, Victoria, British Columbia, 68p. Available from: http:// www.for.gov.bc.ca/tasb/legsregs/fpc/FPCGUIDE/ FishStreamCrossing/FSCGdBk.pdf
British Columbia Ministry of Transportation and Highways. 2000. Culverts and fish passages. Vitoria, British Columbia, 6p. Available from: http://www.th.gov.bc.ca/publications/eng.../ Culverts_and_Fish_Passage.pdf

Burford, D., T. E. McMahon, J. E. Cahoon \& M. Blank. 2009. Assessment of Trout Passage through Culverts in a Large Montana Drainage during Summer Low Flow. North American Journal of Fisheries Management, 29: 739-752.

Castro-Santos, T. 2004. Quantifying the combined effects of attempt rate and swimming capacity on passage through velocity barriers. Canadian Journal of Fisheries and Aquatic Sciences, 61: 16021615.

Castro-Santos, T., A. Haro \& S. Walks. 1996. A passive integrated transponder (PIT) tagging system for monitoring fishways. Fisheries Research, 28: 253-261.

Celestino, E., E. A. L. Kashiwaqui, S. Makrakis, M. C. Makrakis \& J. R. Mariano. 2012. Métodos de coleta para avaliação longitudinal da ictiofauna em riachos interceptados por tubulações. Pp. 115-136. In: Baggio. A. (Ed.). Ecologia de Estradas: tendências e pesquisas. Lavras: Editora UFLA, 313p.

Chilibeck, B. 1992. Land Development Guidelines for the Protection of Aquatic Habitat. Ministry of Environment Lands and Parks.

Clay, C. H. 1995. Design of Fishways and Other Fish Facilities. $2^{\text {nd }}$ ed. Boca Raton, Ann Arbor, London, Tokyo, Lewis Publishers, $248 \mathrm{p}$.

Coffman, J. S. 2005. Evaluation of a predictive model for upstream fish passage through culverts. Unpublished Ph.D. Dissertation, James Madison University, Harrisonburg, Virginia, 105p.

DNIT - Departamento Nacional de Infra-estrutura de Transportes. 2004a. Drenagem - bueiros tubulares de concreto. NORMA DNIT 023/2006 - ES, 8p.

DNIT - Departamento Nacional de Infra-estrutura de Transportes. 2004b. Drenagem - bueiros metálicos executados sem interrupção do tráfego. NORMA DNIT 024/2004 - ES, 8p.

DNIT - Departamento Nacional de Infra-estrutura de Transportes. 2004c. Drenagem - bueiros celulares de concreto. NORMA DNIT 025/2004 - ES, 8p.

Ead, S. A., N. Rajaratnam \& C. Katopodis. 2002. Generalized Study of Hydraulics of Culvert Fishways. Journal of Hydraulic Engineering, ASCE, 128: 1018-1022.

Fullerton, A. H., K. M. Burnett, E. A. Steel, F. L. Flitcroft, G. R. Pess, B. E. Feist, C. E. Torgersen, D. J. Miller \& B. L. Sanderson. 2010. Hydrological connectivity for riverine fish: measurement challenges and research opportunities. Freshwater Biology, 55, 2215-2237.

Harper, D. J. \& J. T. Quigley. 2000. No net loss of fish habitat: an audit of forest road crossing of fish-bearing stream. In: British Columbia, 1996-1999. Canadian Technical Report of Fisheries and Aquatic Science 2319. Vancouver, British Columbia, 43p.

Jones, D. R., J .W. Kiceniuk \& O. S. Bumford. 1974. Evaluation of the swimming performance of several fish species from the McKenzie River. Journal of the Fisheries Research Board of Canada, 31: 1641-1647.

Kemp, P. \& J. O’Hanley. 2010. Procedures for evaluating and prioritising the removal of fish passage barriers: a synthesis. Fisheries Management and Ecology, 17: 297-322.

Kenney, D. R., M. C. Odom \& R. P. Morgan. 1992. Blockage to fish passage caused by the installation/maintenance of highway culverts, prepared by the Appalachian Environmental Laboratory, Center for Environmental and Estuarine Studies, University Maryland for State Highway Administration, Maryland Department of Transportation. 
Langill, D. A. \& P. J. Zamora. 2002. An audit of small culvert installations in Nova Scotia: habitat loss and habitat fragmentation. Canadian Technical Report of Fisheries and Aquatic Science 2422, 34p.

Larinier, M. 2002. Fishways: general considerations. Pp. 21-27. In: Larinier, M., F. Travade, J. P. Porcher (Eds.). Fishways: Biological Basis, Design Criteria and Monitoring. Bulletin Français de la Pêche et de la Pisciculture. Conseil Supérieur de la Pêche. Paris, 364 p.

Larson, D. J. 1976. Stream habitat and forest harvesting. Fisheries Technical Report 76-3. Saskatchewan Fisheries Laboratory, Department of Tourism and Renewable Resources, Saskatoon.

Liao, J. C. 2007. A review of fish swimming mechanics and behaviour in altered flows. Philosophical Transactions of the Royal Society B, 362: 1973-1993.

Mariano, J. R. 2011. Desconexão longitudinal de habitats em riachos neotropicais: assembléias de peixes sob a influência de tubulações. Unpublished Ph.D. Dissertation, Universidade Estadual do Oeste do Paraná, Paraná, 40p.

Mcclellan, T. J. 1970. Fish passage through highway culverts; a field evaluation. Fed. Highway Administration, Region 8 and Oregon State Game Comission, Portland, Oregon.

Monk, B., D. Weaver, C. Thompson \& F. Ossiander. 1989. Effects of flow and weir design on the passage behavior of American shad and salmonids in an experimental fish ladder. North American Journal of Fisheries Management, 9: 60-67.

Morita, K. \& S. Yamamoto. 2002. Effects of habitat fragmentation by damming on the persistence of stream-dwelling charr populations. Conservation Biology, 16: 1318-1323.

Mueller, R. P., S. S. Southard, C. W. May, W H. Pearson \& V. I. Cullinan. 2008. Juvenile coho salmon leaping ability and behavior in an experimental culvert test bed. Transactions of the American Fisheries Society, 137: 941-950.

Nislow, K. H., M. Hudy, B. Letcher \& E. P.Smith. 2011. Variation in local abundance and species richness of stream shes in relation to dispersal barriers: implications for management and conservation. Freshwater Biology, 56: 2135-2144.
Poplar-Jeffers, I. O., J. Petty, J. T. Anderson, S. J. Kite, M .P. Strager \& R. H. Fortney. 2009. Culvert Replacement and Stream Habitat Restoration: Implications from Brook Trout Management in an Appalachian Watershed, USA. Restoration Ecology, 17: 404-413.

Price, D. M., T. Quinn \& R. J. Barnard. 2010. Fish Passage Effectiveness of Recently Constructed Road Crossing Culverts in the Puget Sound Region of Washington State. North American Journal of Fisheries Management, 30: 1110-1125.

Santos, H. A., P. S. Pompeu \& C. B. Martinez. 2007. Swimming performance of the migratory Neotropical fish Leporinus reinhardti (Characiformes: Anostomidae). Neotropical Ichthyology, 5: 139-146.

Santos, H. A., P. S. Pompeu, G. S. Vicentini \& C. B. Martinez. 2008. Swimming performance of the freshwater neotropical fish: Pimelodus maculatus Lacepède, 1803. Brazilian Journal of Biology, 68: 433-439.

Taylor, E. B. \& J. D. Mcphail. 1985. Variation in burst and prolonged swimming performance among British Columbia populations of coho salmon, Oncorhynchus kisutch. Canadian Journal of Fisheries and Aquatic Sciences, 42: 2029-2033.

Toepfer, C. S., W. L. Fisher \& J. A. Haubelt. 1999. Swimming Performance of the Threatened Leopard Dater in Relation to Road Culverts. Transactions of the American Fisheries Society, 128: $155-161$.

Warren, M. L. \& W. G. Pardew. 1998. Road crossings as barriers to small-stream fish movement. Transactions of the American Fisheries Society, 127: 637-644.

WDFW. 2003. Design of road culverts for fish passage. Washington Department of Fish and Wildlife publication. 111p.

Weaver, C. R. 1963. Influence of water velocity upon orientation and performance of adult migrating salmonids. Fishery Bulletin, 63: 97-121.

Webb, P. W. 1975. Hydrodynamics and energetics of fish propulsion. Bulletin of the Fisheries Research Board of Canada, 190: 1-158.

Webb, P. W. 1978. Fast-start performance and body form in seven species of teleost fish. The Journal of Experimental Biology, 74: 211-226. 